\title{
Uma Luz Sobre as Práticas Docentes na Pós- Graduação: a Pesquisa Sobre Ensino e Aprendizagem em Administração
}

Tânia Fischer

UMA Proposta...

Neste texto, formula-se um convite aos programas de pós-graduação em administração, em particular aos programas integrantes da ANPAD. Por razões que serão expostas a seguir, propõe-se que cada programa de pós-graduação institua uma linha de pesquisa, um programa, ou, no mínimo, uma atividade que promova a reflexão sobre o ensino e aprendizagem em Administração. Por que uma linha de pesquisa sobre ensino de Administração? Que significado tem a institucionalização da pesquisa sobre ensino neste momento de transformações radicais nos contextos, conteúdos e práticas de ensinar e aprender?

A primeira contextualização a ser feita é que essas iniciativas institucionais poderão ocorrer no âmbito de um programa indutor de melhorias de ensino, conduzido pela própria ANPAD: O Programa de Capacitação Docente em Administração (PCDA).

Melhorar o ensino de administração na pós-graduação e na graduação é a meta principal do PCDA, que pretende também contribuir para a qualificação e requalificação de professores de Administração.

Compartilhado por 5 instituições na fase de implantação (UFRGS, UFBA, EBAPE, EAESP e PUC/MG), o programa está aberto à comunidade. Compreende atividades de ensino stricto e lato sensu, produção de recursos e materiais de ensino, tendo como objetivo primordial a promoção da reflexão sobre a aprendizagem e as formas de ensino.

É desejável que atividades investigativas favoreçam a criação de "comunidades 
de interesse" nas instituições em momento de transformações radicais nos contextos, conteúdos e práticas de ensino.

\section{...Que Parte de Alguns Conceitos}

Uma linha de pesquisa representa um conjunto de opções conceituais e metodológicas e um compromisso de longo prazo.

Linhas de pesquisa definem-se por temáticas integradoras que têm uma dimensão substantiva (epistemológica, de conteúdo) e outra processual, traduzindo-se em programa, projetos e atividades, métodos, técnicas e instrumentos.

As linhas de pesquisa estruturam-se em função de problemas que justifiquem esforços coordenados e sistemáticos de investigação, tanto pela sua relevância teórica quanto pelo seu impacto social. Podem consolidar conhecimentos ou constituir uma guinada para o desconhecido.

Ademais, linhas de pesquisa comportam uma dimensão estratégica, pois impulsionam projetos que desenham o futuro.

\section{...Contextualizada no Tempo}

A ANPAD nasceu junto com os esforços de institucionalizar a pós-graduação no final dos anos 70, com o objetivo explicito de apoiar a organização do ensino.

Nos anos 80 e, especialmente nos anos 90, a pesquisa ocupou o espaço da formação. Os professores tornaram-se pesquisadores; o CNPq teve importante papel neste impulso para o fortalecimento da área, enquanto produtora de conhecimento. Atualmente, outras agências, como FINEP, fundações estaduais, bancos de desenvolvimento e agências internacionais são também indutoras de pesquisa.

A formação de pesquisadores teve prioridade até o início da primeira década do novo milênio. $\mathrm{O}$ fato de haver um trabalho final dissertativo no mestrado e uma tese de doutorado, como requisito formal dos cursos de pós-graduação, teve como conseqüência o reforço nos currículos de disciplinas e de outras atividades voltadas à formação do pesquisador. Todos os programas têm disciplinas voltadas à formação do pesquisador. Ainda assim, muito poucos têm disciplinas e outras práticas voltadas à formação do professor.

Vivemos um momento de transformação tão importante quanto foi a reforma 
de ensino nos anos 60. Está em trâmite no Congresso Nacional a nova Lei de Diretrizes e Bases, bem como o IV Plano Nacional de Pós-Graduação, já foi finalizado, com importantes mudanças para a pós-graduação em geral e a Administração em particular.

Devido ao contexto de transformações que vive a área e com as políticas de descentralização do ensino superior, há o retorno de um ator esquecido nos últimos vinte anos: o professor.

Formar mais e melhores professores é um imperativo; pois formamos mestres e doutores que têm o direito e o dever de ensinar bem.

Ora, formar professores não é atividade complementar, que se dá inicialmente a partir do aprendizado do conteúdo. Não se dá também, apenas pelo estágio, atividade que alguns programas desenvolvem, simplesmente colocando alunos de pós-graduação no lugar dos seus orientadores em aulas de graduação.

Em primeiro lugar, o professor substituto que chega a uma sala de aula sem preparo adequado na organização e no desenvolvimento do ensino não está fazendo estágio; está exercendo a docência em caráter precário, o que pode ser contraproducente e voltar-se contra a formação pretendida. Igualmente, substituir professores por alunos de pós-graduação afeta a qualidade do ensino de graduação e a formação de mestres na pós-graduação.

Mas, na maioria dos casos, os programas não se voltam à formação docente porque não sabem exatamente como fazê-lo, por um lado; por outro, porque não é uma prioridade valorizada nem pelas instâncias reguladoras (CAPES, especialmente), nem pelos programas que, até recentemente, não tinham consciência de que devem formar mais e melhores professores.

Constatada essa necessidade que está claramente expressa no PNPG 2005/ 2010, qual seja, formar professores, o que e como se pode fazer?

\section{...Tendo como Estratégias}

As estratégias orientadoras da linha de pesquisa sobre ensino de Administração apóiam-se em princípios, centram-se em temáticas geradoras de questões e dependem essencialmente da constituição de grupos de pesquisa ou comunidades de interesse que desenvolvam programas e projetos.

Em primeiro lugar, formar professores deve ser enfatizado como escopo dos 
cursos; a reestruturação dos currículos deve prever a inclusão de modalidades de ensino (disciplinas, atividades, práticas) que objetivam a melhor qualificação do professor, isto porque a formação docente não é explícita nos currículos de pósgraduação.

A existência de atividades de ensino tem como ancoragem a pesquisa sobre ensino e aprendizagem, o que implica a eleição de temas de pesquisa pelos professores e alunos, que gerarão atividades, projetos, dissertações e teses.

Os princípios que orientam o delineamento da linha de pesquisa de Ensino e Aprendizagem em Administração são:

Transversalidade, isto é, incluir projetos de alunos e professores de diferentes campos temáticos, sendo integradora de outras linhas de pesquisa. Por exemplo, um programa que tenha linhas de pesquisa em Organizações, Produção, Tecnologia de Informação, Gestão de Pessoas e Finanças pode ter uma linha de pesquisa que permeie essas áreas de conteúdo e responda basicamente à questão: Como Ensinar?

b) Aplicabilidade, isto é, orientada para a construção de soluções para os problemas do ensino e da aprendizagem, considerando as necessidades de requalificar as propostas de ensino da pós-graduação e de criar esforços de reflexão e propostas concretas para os cursos de graduação, em fase de mudança curricular.

- Integração, pois requer coordenação de esforços entre programas e comporta articulações interinstitucionais, com projetos coordenados, o que pode trazer efeitos benéficos para todo o sistema de ensino de Administração.

Como temáticas possíveis, destacam-se estudos sobre:

- Configurações e transformações na área de Administração como matéria de ensino.

- Desenhos institucionais de redes e unidades de ensino que envolvem processos de internacionalização, articulações nacionais e sub-nacionais, desenvolvimento de programas e mapeamento de tendências.

- Modelos de ensino, testando teorias de ensino e de aprendizagem.

- Desenhos curriculares de pós-graduação e graduação, hoje traduzidos em projetos pedagógicos que oscilam entre indução à criatividade institucional e massificação. 
- Perfis de professores e de alunos, considerando diversidades regionais e peculiaridades institucionais.

- Tecnologias de ensino presenciais, desde ensino tutorial até para pequenos e grandes grupos.

. Tecnologias de ensino a distância.

- Metodologias e recursos típicos do ensino de Administração, como o uso de casos e de jogos de empresa.

. Recursos estéticos no ensino, tais como cinema, música, teatro e outros.

Tais temas, entre tantos outros, podem se constituir em atividades de estudo individual e grupal, em projetos, programas e linhas de pesquisa.

O importante é que reflitam interesses concretos e permanentes que possam reverter no melhoramento do próprio programa, em primeiro lugar.

Na história de cada programa registra-se a evolução da área e o desenvolvimento institucional. Se existe compromisso explícito com a melhoria de qualidade de ensino, deve haver também reflexão sistemática sobre a natureza e organização do ensino, na formação de currículos, nos programas de disciplinas ou atividades pedagógicas de modo geral.

\section{Como conclusão}

Este texto propôs a institucionalização de linhas, programas e projetos de pesquisa sobre ensino e aprendizagem nos programas de pós-graduação em Administração, para subsidiar a formação do professor. O que se propõe, na verdade, é ajudar a refletir sobre as práticas docentes dos próprios programas e também sobre a capacitação de mestrandos e doutorandos nos ofícios e artes de ensino.

Uma linha de pesquisa é, finalmente, uma luz sobre as práticas, de forma a refleti-las criticamente, uma aventura e uma aposta no futuro. 